\title{
CORRECTION
}

\section{Correction to: Neurocritical Care Society Virtual 18th Annual Meeting September 22-25, 2020}

(c) 2020 Springer Science+Business Media, LLC, part of Springer Nature and Neurocritical Care Society

\section{Correction to:} Neurocrit Care

https://doi.org/10.1007/s12028-020-01091-2

The article title was modified in online version to read "Neurocritical Care Society Virtual 18th Annual Meeting September 22-25, 2020".

\section{Publisher's Note}

Springer Nature remains neutral with regard to jurisdictional claims in published maps and institutional affiliations.

Published online: 10 November 2020 